\title{
Pleasure: Redefined By Women in Shobha De's Novels
}

\author{
Ms. Deepanjali Mishra
}

\begin{abstract}
Feminism is a socio- political movement which advocates involved active participation by women to demand for their rights. It can be considered a movement which is fought against female oppression under patriarchy. There are various ways by which a woman can be victimized or we can say that victimization of woman can take place through various ways like caste, colour, race, attitude towards motherhood, etc. The Feminist movement was actually started by white women who basically hailed from middle class in Western Europe and North America. This trend accelerated in1960's with Cool right Movement and the collapse of European Colonialism in Africa, Caribbean parts of Latin America and South Asia. Third Wave feminists advocate for equal rights for the girls and taking charge of their own sexual fulfillment. In her essay, Lusting for Freedom, Rebecca Walker discusses the need for sex education for young women. It recognizes that sexual pleasure is a central part of women's lives and does not discourage women who know how to achieve it without any sense of guilt or regret. The new generation of feminism embraces beauty and power of women's sexuality to achieve their needs. They consider sexual pleasure a human right. Many writers in India have talked of pleasure and its manifestations.
\end{abstract}

The heroines in Ms. De's novels rebuild their lost fortunes; make all efforts to look glamorous by losing weight and spending money in massage parlours. They try to look and act differently from the conventional and traditional women. They love to fall in love with their looks by which they try to attract people. It gives them immense pleasure when people fall head to heels in love with them and they are least concerned about it. Shobha De's doesn't believe in describing her women characters as love slaves or mere help mates at home. Shobha De as a writer tries to mirror or portray her feminist mindset while portraying women in her novels. A broader evaluation of her work reveals her protest against the good old image of women who can't live the way she wants to and do things the way she wants to. Women in her novels are represented as sexually liberated and free thinkers who have been termed as 'New Woman'. These so called new women are much more physically active and athletically strong than their mothers. Feminist- New Style, a journal (1927) declared that "The new woman is a blend of physical freedom, sexuality and stamina with feminist self assertiveness and traditional domestic feminity, a woman who can combine pleasure, career and marriage. They are eager to participate in pleasure as they would do in play, work etc."

All her heroines, be it Karuna, Aparna, Mikki , Alisha or Asha Rani are rebellious modern Indian women who challenge the orthodoxy of social taboos. They are different from the sexually ignorant Indian woman which is quite contradictory to most Indian male writers who feel that sex is as unpleasant subjection to man's desire- necessary in order to have offspring. Shobha De's women challenge this traditional set up in the society. Her women are far more assertive, domineering and bold in comparison to men. They are not submissive, and guilty of their affairs. Sujata, in Sultry Days (1994) is a prostitute, who does what her mind says. This gives her pleasure. Life is defined on her own her own terms. When Asha Rani, in Starry Nights (1991) the famous heroine of Bollywood decides to quit films all of a sudden when she is at the peak of her career just to live with a fellow co star, Akshay Arora, her mother tries to dissuade her from doing it. Then she argues in this way in "Money, money, money. That's all you think of. Well, I'm fed up being your money machine. Ive done enough for everybody- you, Sudha and others- now I want to live for myself. (106)

Asha Rani designs herself a code of conduct for herself which is free from the prescribed gender rules and sexual constraints. This shows clearly that women in Shobha De's novels can't be always taken for granted that they will be dutiful and self sacrificing daughter to their parents. They will certainly revolt when their self interest is at stake. They may face hurdles but they are smart enough to ignore them and break these hurdles very skillfully and tactfully and emerge out of it comfortably.

The novelist has portrayed her women characters in such a way that the readers get a clear picture of her intentions. She has tried her best to expose the normal and spiritual break down of the society which she thinks is in helpless state. Therefore she has understood the human psyche which has made her take a thorough look at the age old customs which bars a woman from doing certain things which she likes to do but is unable to because of the rigid bonds she is bounded with.

Women in upper class society have no concern about public. The concept of morality arising out of love for one and the same person is considered to be outdated. The women in Shobha De's novels believe in 
breaking the age old traditions of enjoying life with pre- marital affairs and extra- marital affairs. She takes a plunge extra into the hearts of the liberated upper class women in contemporary Indian society.

Sex and sensuality are a part of life and in order to accept life one has to affirm sensuality. A woman doesn't consider faithfulness and love a virtue while seeking pleasure. Shobha De's depicts women in their true colours. They are portrayed as what they actually are and not what they should have been. Therefore real pleasure is defined differently for different people. It may mean erotic sex for some women while it may be soft touch and sensual love making as described between Mikki and her husband Binny Malhotra on the moonlit night in his place before their marriage.

The new concept of pleasure envisages complete sexual freedom which is accompanied by economic freedom; uncontrolled passion is sought by Shobha De's women in the form of pleasure. Social rules have always been harsh on women in India. It is justified that a man as an independent being can have extra marital affairs. The society doesn't raise eye brows to those men who leave their wife at home and enjoy with either prostitutes or whores by paying them in cash or kind. No one bothers to think about the woman who is lonely in her home waiting for her husband who doesn't come nights after nights. What she would do in such situation? She can't take her life or ruin herself by crying. A woman is socially not complete without the existence of man in her life and its debarred to enjoy any sexual liaison with any man other than her husband. Her desire for sexual relationship is subordinated to the interest of the society not on her individual feeling.

Rigorous taboos of our society forbid women to have any sort of sexual liaisons by breaking the rigid laws of matrimony in India. However women in Shobha De's novels are broad minded enough to continue with their flings and affairs without bothering about the matrimonial alliance of their partners. These women are confident and are reasonable enough to justify their relationship. This relationship is best exhibited in the relationship between Asha Rani and Akshay Arora in Starry Nights (1991).

The heroines are not ready to obey the superficial social rules which are made by men. Shobha De's women dare to move around and seek pleasure with anyone they like to overcome their mental fatigue. The general norm stated by the society for a woman is to show herself as an active participant in sexual alliance. She is taught not to exhibit her sexual appetite and to participate boldly in sensual activities. Under this servile position, she doesn't have to express her sexual urge which is considered to be against the social taboos. Shobha De's women frame their own culture by breaking these social norms of the society. While writing about women, she doesn't have to be unrealistic because she involves herself completely while writing novels and portraying her women as various characters which she couldn't have realized if she had written about male characters.

Shobha De's women have found various ways of seeking pleasure and they don't hesitate to design their own attitude and behavior which may vary from their counterparts. They are mostly urban women who give less or no importance to the morality and spirituality. They want to be free from the established gender roles and sexual restraints of the traditional society. They want to enjoy the same rights as men. Men regard their women as commodities that can be brought or sold at their own terms and conditions, make women dance to their tunes, and mould them in the concept of traditional servility and make them stand meekly and suffer emotionally, thus women are made to suffer and they have to strive hard to discover the human in them.

Sex contributes a lot in providing pleasure to the women in Shobha De's novels. The writer feels that sex should not be despised or something to be afraid of. She has spoken about the beauty of sex and the change it brings in to the lives of men and women. She has spoken about sex in the following way in Snapshots (1995):"Sex is no longer the most dreaded and despised three letter word in India, is enough to celebrate."(3)

In the urban world a modern woman tries to do anything that comes to her mind, goes to any extent to derive pleasure of her own. The best example of it can be found in the novel Starry Nights, where the heartthrob of millions, queen of Bollywood, Asha Rani tries to derive pleasure in destroying men and the most dreaded weapon that she uses is 'Bed'. Men are unable to forget her once she goes to bed with them. Her bed mates ranged from Kishen bhai, to Akshay Arora to Abhijit, to Jay to Jojo and she even got succeeded to seduce her father's friend in a plane. Sometimes men got afraid of her spell yet they couldn't resist going to her for pleasure and once they went, they were trapped. Asha Rani loved to destroy them, According to her, bed can be considered as a battle field where the battle goes between two human bodies and it's a battle of intellectual ones. Asha Rani won each time this battle was fought. Men hated her, despised her yet had a desire for her.

This battle field gave Asha Rani sensual pleasure and she loved it very much. She is compared to a gangster who is a very pretty woman in the battlefield which is considered to be the bed. Asha Rani's game strategy is that she would first of all judge her enemy's qualities and she had expertise in it. After that when she goes to bed with him, she uses all the tricks that would make him loose out to him and thus giving her all the pleasure in the world.

Asha Rani's source of enjoyment were men and the game she enjoyed playing is love making. Age was not at all a bar for love making. She had sexual encounters with men of his father's age and men who were young enough to be her son like Amar who was a very young and promising star and in fact she had taken a liking for him instantly after meeting him for the first time when they were together for a movie. She had even 
recommended his name his name to the directors to cast him opposite her. To say that he was so desperate to continue with an incomplete scene of their movie in this way in Starry Nights (1991):"Look, remember, that scene in our movie- where the director cut to a bolt of lightning just when our lips were to meet? I'm like suffering from continuity problem. Could I.......that is... (29)

It was Amar who wished her on her birthday when she was thinking about Akshay as he didn't wished her at all. When he called her up and requested to come over and spend the night with her, she immediately agrees to his proposal and welcomes him by wearing a small and youthful T- shirt and tried to be seducing enough by tugging the neck of her costume off one shoulder. Finally they ended up with a sensual love making in her bed room. This has proved a point that the women in Shobha De's novels have made it very clear that they wish to enjoy their life like men without any interference.

Shobha De has tried to portray a man woman relationship which may be very serious yet they can give pleasure to the heroine at the same time. Not only this during the love making sometimes its men who ask them not to stop and deprive them of the pleasure It was Asha Rani who initiated the love making when she was with Akshay and she used various tricks to arouse him and give him pleasure which always culminated in sexual satisfaction and she succeeded in doing it always because after the love making process, Akshay was a contended man.

The traditional Indian woman tries to adjust her nature with her man but it's just the opposite with Shobha De's women. They are independent and free from social and moral restriction. Asha Rani knew that Akshay was married with two sons and was a family man yet she didn't think of sparing him from seducing him and the writer has left no stone unturned to depict the very warm and intimate love making scenes between Asha Rani and Akshay Arora.

Asha Rani found pleasure in the company of Akshay. She had cancelled all the shooting schedules to be with him on his birthday and they celebrated his birthday very sensually in his holiday inn.

The person she remembered most was on her birthday was Akshay Arora. Not only that, Asha Rani was so desperate about the physical intimacy with him that even the abuses by his wife, public insult didn't bother him. The only thing that mattered to her was Akshay and being in bed with him. She always waited for opportunity to win him back into her life. She finally got a chance in the monsoon when she was going for shooting and met Akshay in the traffic. He was persuaded and she succeeded and what followed next was a quiet love making in his Holiday inn in Starry Nights (1991) "Their love making was different. No biting, clawing or frenzied passion. Akshay was gentle and unfrenzied. Asha Rani didn't feel much like a tigress herself. They hardly spoke." (102)

The women in Shobha De's novels don't reject female sexuality. Rather they exhibit different attitude towards sex to contest the established views about the generally and taken for granted view of the human sexual behavior. It makes these women reject the strict social environment that makes the women actually conscious of every small pleasure which may be emotional or physical. It's a very common feature in Shobha De's novels that almost all of the women experience sex with more than one person. Their rejection of sexual morality forms a part of their challenge to the patriarchal way of life that introduces certain curbs on women's behavior.

These women's indulgence in deviant sexual behavior, their attitude towards sexual morality and their use of inhibited language makes their protest against patriarchal system. The women seem to support the radical feminist proposal of replacing the patriarchal way of life. Dominance over the patriarchal system in our society gives rise to sexual revolution which has resulted in making the women bold, wild and lusty. Their activities and thoughts show their belief that a radical change is necessary to make the present system congenial for women and give some space of existence to women.

Shobha De's women characters are very frank about their expression of sexual desire by snubbing the sexual morality which is essentially ordained for women in the patriarchal system existing in India. Their reference to the sexual act in unambiguous terms shatters the traditional image of women that presents her as a submissive, docile, calm and meek.

The writer's bold expression regarding sex is clearly visible from the following lines of Snapshots (1995):"We don't dismiss it. We don't find it dirty. Sex doesn't threaten us. I'm not afraid to fuck. I feel sorry for all you women hanging on so desperately to outdated ideas of purity, morality, chastity. It's pathetic." (226) Sometimes Shobha De has been charged of commercializing women while expressing sex in a much elaborated detail but what I've felt after reading her novels is that she has tried to fight for the cause of women and has brought out the aspect of sex because she feels that women are marginalized even in terms of sex. They are made slaves in the hands of their husbands by making them satisfy their demands whenever they need it. They get cruel and rude even in love making and get enjoyment out of it. Shobha De has portrayed men deriving pleasure by torturing a woman by beating their naked body with hunters or hurting them with making bruises and giving them pain. Therefore the writer has portrayed her women in such a way that they are sexually liberated and use sex on their own terms. 
In the novel Sisters (1992), Shobha De has mentioned that women can make men give them what they want. For example in the following lines she has talked about the joy which a newly wedded wife should feel when she is with her husband: “.......His expertise and imagination were boundless as he excited her in a hundred different ways, touching, licking, nibbling, sucking...... he turned her over, he stood her up, he had her on all fours, and he even had her upside down with blood rushing in a gush into her head. It was unreal, pleasurable, but also a little frightening."(174)

Shobha De has mentioned that a woman can get pleasure even when she is surrendering to a man against her wishes. She enjoys with her protests like the following description in Sisters (1992): "Mikki didn't have time to do anything but savour the myriad physical sensations sweeping over her pliant body as she surrendered to this man who was now her husband. There was no resistance left. And she was happy. And they had broken all the rules and every taboo that she had ever known. She felt liberated, uninhibited and aroused to the point of primitive abandon." (175)

Shobha De has shown in her novels that a woman can be a seeker of pleasure simultaneously. They want it in various ways and the man who gives them using different tricks is very much admired by them. They love these men and can do anything for them. After Mikki got the sexual satisfaction from her husband before marriage, she immediately got married to him without giving second thoughts to her decision.

Contradicting the myth that women should meekly obey their husbands during the love making process, Shobha de's women are aggressive and sometimes become sexually violent to destabilize the idea of male domination. Therefore we can say that the concept of pleasure for Shobha De is complete sexual freedom with no intention of fidelity. Her women love to experience pre marital sexual encounters, post marital affairs and love to explore the forbidden areas which is defined by the rigid norms of the society.

In her novel Second Thoughts (1996), Shobha de has tried to make a point that a woman who is reduced to a lifeless body, mentally tortured by her husband, has no right to spoil her life. She gave her heroine a new dimension by introducing her with another man who could fill her life with colors of joy and give her the pleasure which she was so desperate for. Maya was a very attractive young girl from Kolkata who came to Bombay after getting married to Ranjan who is a bank executive. Ranjan took no interest in her as a woman and had never cared for her interests. He never tried to find out the reason behind Maya's gloominess. He was under the assumption that providing four square meals was more than enough for her and she ought to be grateful for what he was doing for her. Even when Maya made advances to him in bed, he snubbed by saying that he needed time for it.

The entry of Nikhil brought a new meaning to Maya's life. He was a fourth floor neighbor and was a college going student. He may not be interested in studies but he had mastered the art of captivating women. Maya could immediately feel the difference Nikhil brought to her life. Once when he said that she looked fresh and beautiful in blue sari, she started wearing more and more of blue coloured sari. His presence itself brought joy which came from within the heart. She started taking care about her makeup, wore fresh saris, combed and tidied up her hair and neatly put sindoor on the parting of her forehead and tried to look beautiful everyday anticipating his arrival anytime. She was bowled over in their first encounter when he tried to look into his eyes and smiled. She says in Second Thoughts (1996):"But Nikhil most definitely affected me and one part of me didn't 'approve.' This was ridiculous - a newly married woman day dreaming about a neighbour's young son." (45) Pangs of conscience gives way to the sublime urges of the soul in this novel. Extramarital affairs are regarded with more understanding and flexibility. If a woman gets pleasure out of it, she doesn't hesitate in enjoying it. She thinks it to be a ventilator which provides air of sustenance to a soul that's being suffocated in an unhappy surrounding called fate.

Maya is very much aware that Nikhil is the other man in her life. She also knows that by accepting his offer of friendship it would be an act of violation of social and moral code. One day when Ranjan, her husband was on a ten day official tour, Maya got the opportunity to go on an outing with Nikhil to Malabar hills in his motor bike. She allowed herself to be enjoyed and loved in the company of Nikhil where she felt the beauty and pleasure in her life. She admits in this way:"I was ready to jump on Nikhil's motorbike and say 'goodbye' to my uninspiring life without the slightest regret. The choice was frighteningly mine.”(241)

Finally the love making scene depicted by Shobha De between Maya and Nikhil (374) is described as the heights of pleasure experienced by Maya. It was described as smooth, gentle and painless. One day Nikhil came to her house and announced it was his birthday and without giving any chance to Maya to react, he embraced her and the writer has written in elaborate details what followed after this in this way:" But Nikhil's mouth covered mine gently. His eyes were shut and his hands were in my untidy hair with the bouquet getting caught in the tangles"

The kiss between Maya and Nikhil is described by Maya as so complete and focused in the following way:"It was a kiss that involved Nikhil's entire being. A kiss so focused, so complete. I surrendered to its soft urgency even though my mind was on mundanities like the washerwoman showing up earlier than usual. " (376-77) Maya has described these moments as the most wonderful, the most unimaginable and moving 
experience of her life. Nikhil filled Maya with the power and pleasure that she was so much desperate about. She had found meaning in her existence in this world. "Nikhil had mastered the art of love making and was very composed and well acquainted with the Physical needs of a woman and to give her the pleasure. "(379)

Shobha De's novel Snapshots (1995) also has depicted about a woman's needs, desires and pleasures. This novel too has emphasized the fact that sexual pleasure is a very important need for a woman. Shobha De's women characters in this novel speak about different aspects of love, sex and life. We can know about the writer's intention from the very first sentence,' Prem liked to make love in public places' which gives the reader the impression of pleasure from the view of a woman.

The women in Snapshots want to enjoy life and give in easily to sex which shows the women's weakness for sex and their sexual enjoyment in life. Talking about sex and participating about sex oriented conversation gives them immense pleasure. That seems to be the only topic of discussion when women are in the company of women.

Swati. One of the seven women friends in snapshots loves to be in the company of girl friends or otherwise prefers to be alone though she also loves sex and is a hard core seeker of pleasure by using men. The anger against men and the male dominated society and the relief of being alone in the absence of men make these women free to enjoy life without any strings attached to them. Shobha De has tried to emphasize this point by describing a scene in Snapshots where she has displayed her imaginative skill. When the women were enjoying a get together in Reema's home and suddenly they wanted to discuss on a particular topic, Swati announces that 'nobody is watching' in the following way:

Since enjoyment of life is the prime motive of these elite class women, they try to voice against the traditional norms of the society and the joint family system. The women are very assertive and want to do two things at a time. That means they want to ask the mother- in law to stay away from their ways and at the same time, they want their husbands to do what they want him to do.

Shobha De has portrayed about many forbidden relationships in Snapshots which were established just for pleasure. The very common relationship is about Reema's relationship with her brother- in - law who was in America. They had a sort of arrangement that whenever Randhir,(Reema's brother- in- law) came to India, Reema would be engaged with him and provide him with all the sexual pleasure. This affair was completely unknown to her husband. She herself confessed this to her friends that she was not in love with Randhir. Their love making portrayed by Shobha De clearly indicates that it was pleasure and nothing else. Both are pretty free with each other. Randhir criticizes her for being a typical Indian wife like this: "Relax woman, I'm not the first man to do it to you surely. Reema shut her eyes and put her arms around Randhir. The feel of his smooth bare back under her fingers made her tingle all over and she felt her body unwinding gradually. She moved her hips, shyly at first, and then with a rhythm that was aggressive and insistent. She arched herself to receive him better, her breasts straining to make contact with the rough hairs on his chest. Soon the bodies were moving together perfectly synchronized and she could hear Randhir grunting in deep arousal as he drove himself harder, locked into a double embrace created by her arms and legs as she held him firmly, passionately to herself as if afraid of letting go." (158)

They have opined that sex is a hobby which gives pleasure to her. These people feel happy when their husbands aren't around and come late from office like Reema says:

"Yes, it rather suits me. We have hardly anything to talk about. This way I have the whole day free for myself. I go to the Priyadarshini park every evening for a long walk. Then I come home and chat on the phone. We plan out our kitty lunches, shopping trips for the next day. What to make for dinner. Holiday plans. It's much better this way. He's so tired at night. He finishes his dinner in ten minutes and goes to sleep. On days when I want to watch movies or read, I sleep in the next room." (228-9)

Sexual expressions, physical intimacy have been maintained as befitting background for an in depth analysis of the modern Indian society in which a woman always finds herself at the receiving end. Sometimes men seek pleasure from a prostitute where a woman is commercialized. However Shobha De's novels make the reader analyze that a woman who sells her body for money is a giver of pleasure to a man like Swati, who commodifies her body in the name of sexual autonomy. She is used by the men made object of physical desire and represents the hundreds of women who want to become famous and achieve quick success. She feels if a woman is seeker of pleasure, she should shun the predicament female ideas the purity, morality and chastity as mentioned in the following paragraph of this novel: "Aparna had grown up with shame. Shame about her body. Shame about her adolescent looks. Shame about her background. Shame practically about every aspect of her life. It was the environment she was raised in. Guilt was its defining feature. She couldn't recall a time when she wasn't made to feel acutely conscious of every small pleasure- emotional or physical." (9)

Women in Snapshots try to make themselves happy by breaking the age old tradition to be committed to one man. They have fun, enjoy on the basis of multiple partners and even they never feel ashamed of public. Aparna gives a very good example of this situation where she had a troubled marriage with Rohit; she had shed her commitment image and took life as it was. She enjoyed her life flirting with Prem, who was her employee, 
made love with him in public in the seas of Goa but she wasn't emotionally attached with this man as she says in this novel: "No, Aparna was definitely not in love with the man. She knew for sure. But she needed him- both at work and at play. Prem was a convenience. A cold blooded one. But what the hell. It worked the same way for him too. What's more, he got paid for "(4)

Urbanized Indian women live their own life, and are unconcerned to the self appointed guardian of cultural values. They have complete control over their sexuality and play dangerous game of outplaying men. Pleasure is experienced by both men and women from within despite their social and psychological constraints. Romance, sex, glamour provide peace and pleasure because the couples have been in quarrel, they are bored and suffer from infidelity. Inside a boring relationship, sexual escapades may be the only popular discourse that highlights the question of women's erotic pleasure. De's women are dissatisfied and unhappy in sexual slavery in the hands of men.

Men are indifferent to women's individuality, sensitivity and feelings. These women are victim of infidelity, and uncommitted relationship which makes these women seek for pleasure outside their marriage. These women are in search of personal freedom. They express their anger by resorting to what might be termed as unethical acts like indulging in extramarital affairs.

Lesbianism is a counter revolution against the foundation of male privileged society. It refuses male authority in sexual terms where woman's feelings and desire for sexual pleasure are discarded. In sexual arena, Shobha De's women don't want to be dominated as an object as a subordinate person.

Therefore the writer has tried to prove a point that a woman is so independent that she doesn't have to depend on a man for seeking pleasure always. She can also find her alternatives where she can discard a man out of her life as she has successfully done while seeking economic independence and marriage. Pleasure may be the source of happiness for a woman but it is not the man who is the only alternative, rather a woman can also prove to be a seeker as well as a provider of pleasure.

\section{References:}

[1] Barche, G.D. The Fiction Of Shobha De Jaydipsinh Dodiya, ed. New Delhi: Prestige. 2000

[2] De, Shobha. Snapshots. New Delhi: Penguin India. 1995

[3] De, Shobha. Starry Nights. New Delhi: Penguin India, 1991

[4] Shukla, Bhaskar. Feminism and Female Writers. Book Enclave.2007.

[5] De, Shobha. Second Thoughts. New Delhi: Penguin India, 1996 